Pobrane z czasopisma Studia Bia?orutenistyczne http://bialorutenistyka.umcs.pl Data: 26/04/2023 14:37:59

DOI:10.17951/sb.2020.14.87-101

Studia Białorutenistyczne 14/2020 HISTORY, CULTURE AND SOCIOLOGY

ISSN: 1898-0457 e-ISSN: 2449-8270

Licence: CC BY 4.0

\title{
Siarhei Marozau
}

Yanka Kupala State University of Grodno (Belarus)

e-mail: banifacyj@mail.ru

ORCID: https://orcid.org/0000-0002-7331-0785

\section{Stefan Batory in the Historical Memory of Grodno and Grodno Residents (the $20^{\text {th }}$ - beginning of the $21^{\text {st }}$ Century)}

Stefan Batory w pamięci historycznej Grodna i jego mieszkańców (XX-początek XXI wieku)

Стэфан Баторый ў гістарычнай памяиі Гродна і гродзениау (XX-nачатак XXI cm.)

\begin{abstract}
The actualization of the epoch and personality of the King of Poland and the Grand Duke of Lithuania Stefan Batory took place in modern Belarus on the wave of growing scientific and public interest in the political history of the Grand Duchy of Lithuania and the PolishLithuanian Commonwealth, neglected in Soviet times. The historical memory of him is most firmly established in the Grodno region and has a 100-year tradition. The article substantiates the reason for this phenomenon - first of all, the city of Grodno owes its worthy status of being a royal city as well as its high historical image to Batory. The 'places of memory' left by Batory in Grodno and their European significance are shown: the Old Castle is the only remaining royal castle in Belarus (except the New Castle), in the 1930s it was supposed to be transformed into the 'Wawel over the Neman', an analogue of Krakow Wawel; 'Batoryevka', known in the history of European medicine (the resting site of the body of Batory); the Vytautas Fara, the most famous Belarusian church destroyed by the communist authorities, which became a symbol of Grodno. Three stages of the evolution of the memory of Grodno and Grodno residents about Batory in the $20^{\text {th }}$ - early $21^{\text {st }}$ centuries are described: from the strong presence in the Grodno tradition from 1919 to 1939 through the transformation into a 'white spot' of history in Soviet times (the king who made campaigns to the East, could not be a symbol of the city) to 'rehabilitation' in the 1990s and an increasing presence in memory in recent years. The contribution of Grodno

* Financing: Funded from the budget of the Institute of Modern Languages and Literatures and the Institute of History of Maria Curie-Skłodowska University, from the funds of the Minister of Science and Higher Education for activities promoting science (contract no. 615/P-DUN/2019) and under the 'Support for Academic Journals' programme (contract no. 331/WCN/2019/1).

Publisher: Wydawnictwo UMCS
\end{abstract}


historians (Yu. Yadkovsky; scientific events organized by D. Karav) to the historical memory of the inhabitants of the region is emphasized. The forms and ways of manifestation of memory are identified: the nationwide character of celebrations of 1933 in honour of the $400^{\text {th }}$ anniversary of the birth of Batory (apogee of his honour); the inclusion into the modern calendar of memorable dates of the day of remembrance of Batory (December 12), the installation of the monument to the lost churches on the site of Vytautas Fara (2014) and the discovery of new circumstances of its tragedy in 1961, 'Stefan Batory Festival' and others. There are three approaches to Batory of modern Grodno: from his recognition as a strong political figure among the figures of Eastern and Central Europe in the second half of the $16^{\text {th }}$ century and his contribution to the development of Grodno through a neutral attitude to its exclusion from urban history (because he favoured the Jesuits, 'suppressed' the locals). Recently, public opinion of the city is concerned about the reconstruction of the 'Vytautas Fara' church, the reconstruction of the Old Castle, and the installation of a monument to Batory. These issues acquire a new practical meaning in the context of the development of Grodno as a tourist centre. Their solution can give a strong impetus to the tourism business in Belarus.

Keywords: Grodno; Stefan Batory; historical memory; 'places of memory'

\begin{abstract}
Abstrakt
We współczesnej Białorusi zainteresowanie postacią króla Polski i wielkiego księcia litewskiego Stefana Batorego oraz jego epoką należy tłumaczyć rozwojem badań naukowych poświęconych zaniedbanej w czasach sowieckich historii politycznej Wielkiego Księstwa Litewskiego i Rzeczypospolitej. Posiadająca stuletnią tradycję i zakorzeniona najsilniej na Grodzieńszczyźnie pamięć historyczna o władcy jest związana z rolą, jaką odegrał on w dziejach miasta: Grodno zawdzięcza Batoremu pozycję miasta królewskiego i atrakcyjny wizerunek historyczny. W oparciu o topografię Grodna w artykule omówiono miejsca związane z Stefanem Batorym: Stary Zamek jako jedyny zachowany po dziś dzień zamek królewski na Białorusi (oprócz tzw. Nowego Zamku), który w latach trzydziestych XX w. planowano przebudować na wzór krakowskiego Wawelu (tzw. Wawel nad Niemnem), znana w historii europejskiej medycyny Batorówka (miejsce przeprowadzenia sekcji zwłok Stefana Batorego), kościół Najświętszej Maryi Panny (zwany też Farą Witoldową) - najsłynniejszy białoruski kościół zniszczony przez władze komunistyczne, symbol Grodna. W artykule opisano trzy etapy ewolucji pamięci mieszkańców Grodna o Batorym w XX i na początku XXI wieku: od pozytywnego wizerunku w latach 1919-1939, poprzez biała plame w historii w czasach radzieckich (król wyprawiający się na Wschód nie mógł być symbolem miasta), do „rehabilitacji” w latach 90. i dużego zainteresowanie postacią króla w ostatnich latach. Autor podkreśla wkład historyków Grodna (J. Jadkouski; wydarzenia naukowe organizowane przez D. Karawego) w projekty kultywujące pamięć historyczną mieszkańców regionu. Omówiono formy i sposoby manifestowania pamięci o Batorym: ogólnokrajowe obchody 400-lecia urodzin Batorego w 1933 r. (apogeum jego czci); wpisanie do współczesnego kalendarza pamiętnych dat dnia pamięci Batorego (12 grudnia), ufundowanie na miejscu Fary Witoldowej pomnika upamiętniającego dawny kościół (2014) oraz ujawnienie nowych okoliczności wyburzenia świątyni w 1961 r., „Święto Stefana Batorego” i inne. Opisano różne oceny Batorego jako władcy w opinii współczesnych mieszkańców Grodna: od pozytywnych, uznających go za silną postać polityczną w Europie Wschodniej i Środkowej drugiej połowy XVI w. do negatywnych, związanych z postulatem usunięcia króla z historii miasta (ponieważ faworyzował
\end{abstract}


jezuitów, „tłumił” miejscowych). Omówiono zagadnienia, które w ostatnim czasie nurtują opinię publiczną miasta: odbudowa Fary Witoldowej, przebudowa Starego Zamku i ufundowanie pomnika Batorego. Kwestie te nabierają nowego znaczenia w kontekście rozwoju Grodna jako ośrodka turystycznego. Ich uregulowanie może dać silny impuls dla rozwoju turystyki na Białorusi.

Słowa kluczowe: Grodno; Stefan Batory; pamięć historyczna; „miejsca pamięci”

\section{Анатацыя}

Актуалізацыя эпохі і постаці караля польскага і вялікага князя літоўскага Стэфана Баторыя адбылася ў сучаснай Беларусі на хвалі ўзмацнення навуковай і грамадскай цікавасці да палітычнай гісторыі Вялікага Княства Літоўскага і Рэчы Паспалітай, занядбанай у савецкі час. Гістарычная памяць пра яго найбольш трывала ўмацавалася на Гродзеншчыне і мае ўжо 100-гадовую традыцыю. Артыкул абгрунтоўвае прычыну гэтай з'явы - найперш Баторыю горад Гродна абавязаны годным статусам каралеўскага горада і высокім гістарычным іміджам. Паказаны “месцы памяці", якія пакінуў Баторый у Гродна, i ix еўрапейская значнасць: Стары замак - адзіны на Беларусі (акрамя Новага замку) захаваны каралеўскі замак, у 1930-я г. меркаваны для ператварэння ў “Вавель над Нёманам", раўназначны кракаўскаму Вавелю; «Батор'еўка», вядомая ў гісторыі еўрапейскай медыцыны (месца анатаміравання цела Баторыя); Фара Вітаўта - самы вядомы беларускі храм, знішчаны камуністычнай уладай, які стаў сімвалам Гродна. Ахарактарызаваны тры этапы эвалюцыі памяці Гродна і гродзенцаў пра Баторыя у XX - пачатку XXI ст.: ад трывалай прысутнасці ў традыцыі Гродна ў 1919-1939 г. праз ператварэнне ў „белую пляму” гісторыі ў савецкі час (кароль, які рабіў паходы на ўсход, не мог быць сімвалам горада) да “рэабілітацыі” ў 1990-я г. і ўзмацнення прысутнасці ў памяці ў апошнія гады. Падкрэслены ўклад гродзенскіх гісторыкаў (Ю. Ядкоўскі; навуковыя мерапрыемствы, арганізаваныя Д. Каравым) у гістарычную памяць жыхароў краю. Раскрыты формы і спосабы праяўлення памяці: агульнадзяржаўнага характару ўрачыстасці 1933 г. у гонар 400-годдзя нараджэння Баторыя (апагей яго ўшанавання); уключэнне ў сучасны каляндар памятных дат дня памяці Баторыя (12 снежня), усталяванне помніка страчаным храмам на месцы Фары Вітаўта (2014 г.) і адкрыццё новых абставін яе трагеды 1961 г., «Фестываль Стэфана Баторыя» і інш. Выдзелены тры падыходы ў стаўленні да Баторыя сучасных гродзенцаў: ад яго прызнання моцнай палітычнай фігурай сярод дзеячаў Усходняй і Цэнтральнай Еўропы другой паловы XVI ст. і ўкладу ў развіццё Гродна праз нейтральнае стаўленне да вырачэння яго з гарадской гісторыі (бо спрыяў езуітам, “душыў” мясцовых жыхароў). Названы пытанні, якія вярэдзяць гарадскую грамадскую думку ў апошні час: адбудова храма “Фара Вітаўта”, рэканструкцыя Старога замку, усталяванне помніка Баторыю. Гэтыя пытанні набываюць новы практычны сэнс у кантэксце развіцця Гродна як турыстычнага цэнтра. Іх вырашэнне можа даць моцны штуршок для турбізнеса Беларусі.

Ключавыя словы: Гродна; Стэфан Баторый; гістарычная памяць; „месцы памяці” 
$\mathrm{T}$ The life and activity of a number of famous political figures of the epoch of the Grand Duchy of Lithuania and the Polish-Lithuanian Commonwealth are closely connected with Grodno: Vytautas, Saint Prince Casimir, Casimir Jagiellon and Stanislaw August Poniatowski. But the worthy status of the royal city and the high historical image the city is owed to the King of Poland and the Grand Duke of Lithuania Stefan Batory.

Batory first came to Grodno in 1579 - there was a meeting of the Senate, which discussed the contribution of the Grand Duchy of Lithuania in the Livonian War. He liked the city. He appreciated the strategic importance of Grodno and, in order to be closer to the theatre of war operations and unwilling to depend on court intrigues in Krakow and Vilnius, moved the royal residence there - in fact, he moved the capital of the Polish-Lithuanian Commonwealth and the military headquarters. Since then, Batory visited Grodno a dozen times, and he spent the better part of the last two years of his life (1584-1586) without leaving.

The monarch reaffirmed to the city all the former rights and privileges, providing it in economic affairs with broad autonomy and freedom of trade. Batory contributed to the development of Grodno with many innovations. A Catholic by faith, he introduced the Gregorian calendar in 1582, but was tolerant of other religions and peoples of the Commonwealth: he left the Orthodox Church the right to use the Julian calendar; granted the privileges to the Grodno Transfiguration Cathedral; supported the Jews.

King Stefan turned Grodno into the centre of political life of the state and decorated it with new buildings: the Renaissance palace on the Rynachnaya Square - 'Batoryevka'; the majestic brick church 'Vytautas Fara' (the 'magnificent church' as it was described in 1587 in a message to Rome). For his residence, he ordered the reconstruction of Vytautas Castle on Castle Hill. For this purpose, a large group of architects, builders, and craftsmen from the Grand Duchy of Lithuania and from abroad were invited. Built in accordance with the latest architectural trends, the Old Castle turned into a magnificent royal residence, and the city received a beautiful palace, which had no equal then in the Commonwealth.

Changing the course of the Livonian War, Batory saved the Grand Duchy of Lithuania and gave the Commonwealth several decades of peace. In Grodno, he developed plans for new campaigns to the East and conducted their diplomatic preparation. King Stefan made a significant contribution to the strengthening of the Commonwealth, raising its prestige in Europe.

A year before his death, Batory made a will by which he bequeathed 30 thousand florins (about 6 million dollars according to a very approximate change into modern currency) to his 'beloved Grodno'. The King died in Grodno and was first buried there in the crypt of Fara church.

None of the kings of Poland and the Grand Dukes of Lithuania paid as much attention to the development of the welfare of Grodno as Batory. It is no coincidence that not only contemporaries but also descendants called Grodno the 'city of Batory' (Gryckevič, 1994; Gryckevič, 1999), and the historical memory of Stefan Batory in 
Belarus was most strongly strengthened in the Grodno region (Karaŭ, 2004, p. 122). 'If we look at the urban tradition', the one-day newspaper W rocznice 153319181933 wrote in November 1933:

we will find neither Vytautas nor St. Casimir, nor the sad memory of Stanislaus August. Only Batory is still alive in the minds of Grodno residents, who created a whole legend about his life and death in the city above the Neman River. This city ... especially fell into the heart of the warrior-king, who said that it was most dear to him both for temporary life and eternal rest (W rocznicę, 1933, pp. 4-5).

The memory of Batory is preserved in the region in the legends and toponymy, in written monuments and relics, in the architectural heritage and works of Grodno historians and regional ethnographer (Karaǔ, 2004, p. 122).

Significant scientific literature, primarily Polish and Hungarian, is devoted to the figure of Batory, who occupies an important place among the famous personalities of Eastern and Central Europe in the second half of the $16^{\text {th }}$ century. Historians of Poland and Russia interpreted his activity on the basis of different, sometimes antagonistic theoretical and methodological attitudes and the national and state interests of their countries. Belarusian historiography has repeatedly changed its ideological principles and political affiliations in the approach to the activities of this ruler. But scientific objectivity has forced us to recognize the historical greatness of this figure, even by historians with polar views.

Russian historiography from the $19^{\text {th }}$ century to the present day interests in Stefan Batory in the context of the Livonian War (Novodvorskij, 2015; Penskoj, 2019; Filûškin, 2017), and modern Belarusian historical science - also in the context of his plans for military revenge, which were hatched in 1584-1586, among others, in Grodno (Laškevič, 2010).

Batory's sudden death in Grodno on December 12, 1586, when he was making the most daring plans to march on Istanbul through Moscow, became a secret for his contemporaries and remained a shrouded mystery for centuries. The death of the crowned patient caused controversy between the court doctors, the Italians Simoni and Buchello, and was later reflected in hundreds of pages of their written disputes. Thanks to these disputes, the story of the last days of the ruler's life is known to us by the hour and even down to the minute. But historians and doctors, primarily Hungarian and Polish, are still trying to solve the mystery of his death. Thus the works of Tadeusz Jankowski (Jankowski, 1930), Witold Ziembicki (Ziembicki, 1937) and Zdzislaw Scheuring (Scheuring, 1964), Daniel Baga, Zsolt Molnar, Tomasz Molnar together with Nikolaj Shumin (The Death of Stefan Batory, 2018) appeared.

Belarusian historiography has not yet created a detailed work on Batory. At the same time, the theme of 'Stefan Batory and Grodno' was reflected in the articles of Grodno historians, many of whom are not experts on the second half of the $16^{\text {th }}$ century, and in many popular materials of local historians. This is an important part 
of the historical memory, which through popular publications, mass media, and internet resources becomes the property of Grodno residents and guests of the city from different countries and continents. There are even special articles about Grodno residents honouring the memory of Batory in the interwar period of 1918-1939 by Professor Jerzy Milewski (Bialystok) (Karaŭ, 2004, pp. 166-171; Milewski, 1999) and local historian Tatsyana Kazak (Grodno) (Kazak, 2013).

The first person to inscribe Stefan Batory into the history of Grodno was the local historian Eustachy Orlovskij (1863-1913), the author of the first generalizing work on the history of the city (Orlovskij, 2011, pp. 95-97). But special merit in the return of the figure of Stefan Batory to the historical memory of Grodno belongs to the student of E. Orlovskij Jozef Jadkowski (1890-1950) (Bibliografiâ Iosifa Iodkovskogo).

According to J. Milewski, the return of the memory of Batory to the Grodno tradition began shortly after the end of the First World War, when the city became part of the Second Polish Republic. As early as 1919, the main city square, formerly known as Handlowa, Ratusznaya, Paradnaya, Sabornaya, and Farnaya, was renamed Batory Square. It marked the celebration of important state anniversaries and holidays, as well as revolutionary demonstrations of workers (Karaŭ, 2004, p. 167).

The palace, which was altered by subsequent alterations and partially destroyed, and which is firmly entrenched in the memory of Grodno residents as 'Batoryevka', has remained in this square. During the construction of the royal palace on Castle Hill, it served as the residence of the monarch. This building is still considered to be the final resting site of Batory's body after his death.

The mighty 'Vytautas Fara', built in 1584-1587 on the initiative of King Stefan, has been preserved in the same square. After his death, his body rested here in the crypt for more than a year. The 'Vytautas Fara', given in 1804 to the Orthodox Church, renovated after a fire and rebuilt in the late $19^{\text {th }}$ century in the pseudo-Russian style, was returned to the Catholics in 1919 and used as a garrison church. The fires of 1923 and 1935 led to the reconstruction of the church.

The square was also decorated with the Fara (former Jesuit) church, built in the $17^{\text {th }}-18^{\text {th }}$ centuries. But it was also identified with the name of Stefan Batory, who played a major role in the appearance of the Jesuit order in the Grand Duchy of Lithuania and Grodno, and in 1584 he had donated funds for the construction of the Grodno Jesuit Collegium.

During the interwar period, the name 'Batoryevka' began to be used in relation to one of the city schools on Pilsudski Street (now Lenin Street). In 1928 it was the fourth largest school in Grodno (343 students). Young people from the Grodno region studied in large numbers in Vilnius at the Stefan Batory University, opened in 1919 in the place of the former Vilnius University (Karaŭ, 2004, p. 167).

In 1922, Jozef Jadkowski, then a well-known historian and expert on ancient monuments of the former Polish-Lithuanian Commonwealth and their custodian, created a three-room Historical Museum in the old prefect building on the basis of preserving and saving exhibits. In 1924, he persuaded the corps command in Grodno 
and the city authorities to transfer part of the Old Castle associated with Batory and his era, in which there was the House of officers and other military organizations, to the State Museum. It took several years to restore the Castle, to strengthen the Castle Hill and to create a new exposition of the Museum, which is now located in five rooms. The staff of the Museum consisted of three people; J. Jadkowski headed it until 1936.

In the 20s and 30s, J. Jadkowski published in the Grodno newspapers Echo Grodzieńskie, Nowe Życie, Glos Prawdy Ziemi Grodzieńskiej and printed in other publications many articles that inscribed the name and activities of Stefan Batory in the historical memory of the inhabitants of Grodno (Bibliografiâ Iosifa Iodkovskogo).

In 1929, at the suggestion of the President of the city, it was decided to issue the 'Historical Library of Grodno'. The first book was published the following year. It was Śmierć Stefana Batorego w Grodnie (The Death of Stefan Batory in Grodno) by Tadeusz Jankowski (Jankowski, 1930). J. Jadkowski placed in the book Inwentarz rzeczy pozostałych po śmierci króla JMci Stefana, spisany w Grodnie 1586 roku (Inventory of Things Left after the Death of King His Highness Stefan, Written in Grodno in 1586) with his comments (Jankowski, 1930, pp. 53-70).

The apogee of honouring the honorary citizen of Grodno in 1579-1586 was the celebration in the city in 1933 of the $400^{\text {th }}$ anniversary of the birth of Stefan Batory. Three years later, not on such a large scale, the $350^{\text {th }}$ anniversary of his death was celebrated. The preparation and organization of the celebrations were carried out by a specially created Voivodship Committee, which worked under the patronage of the President of Poland Ignacy Moscicki.

One of the tasks of the Committee was to restore the residence of Batory - the Old Castle. It was an ambitious and expensive undertaking, so its implementation took several years. It was assumed that the restored castle would become for the region such a Wawel over the Neman, equivalent to the Krakow Wawel. As J. Jadkowski wrote in 1933, Grodno was considered to be the second city in the North-eastern lands of the Polish-Lithuanian Commonwealth after Vilnius in terms of the number of monuments preserved there. He expressed the hope that the restored Old Castle would become the temporary residence of the head of the state, and as a treasury of rarities and monuments of the first-class scientific value of the region, would play the role of the Neman Wawel (W rocznicę, 1933, pp. 12-13).

At its meeting on March 9, 1933, the Grodno City Council adopted the following resolution:

Stefan Batory chose Grodno as his residence during his famous campaigns. In Grodno Castle, he considered plans aimed at great victories and strengthening the power of the Commonwealth. In Grodno, the great king completed his glorious life. [...] In 1918, Grodno and the Grodno region began to create the Polish army, which, following Batory, marked the eastern borders of the revived Rzeczpospolita. The City Council decided to appeal to the Minister of War, Marshal Jozef Pilsudski, with a request to approve officially for the volunteer regiment formed at that time from Grodno citizens, who had arbitrarily appropriated the 
name of Stefan Batory, the name of the 81st King Stefan Batory Regiment (DAGO, f. 46, inv., d. 281, p. 74).

On November 9, 1933, the Grodno City Council discussed the expenses for the celebration of the $400^{\text {th }}$ anniversary of the King's birth. In the budget for 1931/1932, 1,000 PLN were allocated for this purpose. However, this was not enough to cover even the most necessary expenses. As the protectorate over the celebrations in honour of Batory was taken over by the President of Poland, they acquired a nationwide character and, accordingly, required proper preparation of events, which entailed unforeseen expenses. The City Council approved a budget for the celebrations in the amount of 7,200 PLN, including 650 - for tidying up the external appearance of the building of the City Council; 1,100 - to refresh the facade of the theatre building, as well as its cloakroom, foyer, and buffet; 1,000 - for the construction of the triumphal arch, the decoration of the theatre, the installation of the altar; 250 - for the uniforms of the city service workers, 1,200 - for the purchase of 600 lamps, 2,500 - for the guest reception, in particular, for the breakfast during the arrival of the President, and 500 for transportation and other expenses (DAGO, f. 46, inv. 1, d. 281, pp. 216).

On November 25-26, 1933, the attention of the entire region was focused on Grodno, where celebrations were held on the occasion of the $400^{\text {th }}$ anniversary of the birth of Stefan Batory, for whom this city, according to a special appeal of the Voivodeship Committee, was the spiritual capital. The ceremony was attended by many important guests, including the President of Poland. All hotels were occupied. Never before, as it was noted by the press of the time, had the city seen so many limousines, top hats and beaver collars. It was decorated with portraits of Batory, and shone with purple and the brilliance of illumination. At the festive breakfast, which the city authorities arranged for 180 guests in the officers' casino, in addition to the President, there were Catholic and Orthodox bishops, ministers, the ambassador of Hungary. In the evening, the city theatre showed the guests a historical play Batory near Pskov by the Vilnius journalist Valerian Kharkevich. The pediment of the theatre building was decorated with a huge map of the Commonwealth of Batory times. After the performance there was a party in the Old Castle. It was given by the President of Poland as a new honorary citizen of the city (Karaŭ, 2004, p. 168).

On the second day, solemn Masses were held in the churches of all denominations. After the Mass in the Fara Church, the Voivode paid tribute to Batory in his speech. Then a parade of troops and military equipment took place in Batory Square. The last official event of the holiday was the unveiling by the President of Poland of a memorial plaque in honour of Stefan Batory on the building the Old Castle (Karaǔ, 2004, p. 169). With his participation, a brief meeting of the Committee on the restoration of the royal residence took place in the Castle. A three-year period was set for its restoration (Kazak, 2013, p. 128). The restoration work carried out in the Old Castle in 1933-1937 is reflected in the published report of the Committee for honouring the memory of Batory in Grodno (Sprawozdanie Wojewodzkiego Komitetu, 1938). 
The 81st Grodno Rifle Regiment, which co-organized the festivities, was named after King Stefan Batory. The soldiers of this regiment began to wear the initials 'SB' and the image of the crown on their armbands. The $27^{\text {th }}$ Uhlan Regiment, stationed in Nesvizh, was also named after S. Batory (Karaǔ, 2004, p. 169).

In 1933, the one-day newspaper $W$ rocznice 153319181933 was published, devoted mainly to the anniversary of Batory (W rocznicę, 1933).

The $350^{\text {th }}$ anniversary of Batory's death was celebrated in Grodno on December 12, 1936 on a smaller scale, but with due solemnity. This time there were no high-ranking officials or crowds of citizens. This day commemorated the King's services to the city, which owed him its development and the castle. Bells rang in all the temples. There was a guard of honour near the memorial plaque in the Old Castle. A candle burned under the sign. A cannon salute sounded. The orchestra played the national anthem. Then a mourning Mass was served in the garrison church - the former Vytautas Fara, where Batory's ashes were buried in 1586-1587 (Karaǔ, 2004, pp. 169-170). The next day, the theatre staged 'Stefan Batory' (Kazak, 2013, p. 128).

In the late 1930s, the Union of Orthodox Poles named after Stefan Batory was established in Grodno (Karaǔ, 2004, p.170).

In Soviet times, the King, who marched East, could not be a symbol of Grodno. In general, by the early 1990s, his life and activity had become one of the many 'white spots' in the history of Belarus (Karaŭ, 2004, p. 179). After the Great Patriotic War, the State Historical Museum resumed its activities with a diminished collection in the former Royal Palace. But only at present, the portrait of the former owner of the Palace began to greet Museum visitors.

In November 1961, in accordance with the Soviet policy of fighting religion, on the orders of the Grodno City Council, Vytautas Fara was blown up by a demolition team called in from Leningrad. This mighty building of the Catholic Church, built by order of Batory and buried in it according to his will, became the most famous Belarusian church destroyed by the communist authorities. This act of vandalism became a lasting wound in the history of Grodno.

With the acquisition of sovereignty by Belarus, there was a demand to rethink its historical path, interest in the neglected Soviet times, the political history of the Grand Duchy of Lithuania and the Polish-Lithuanian Commonwealth increased, and there was the actualization of the era and figure of Stefan Batory in scientific and social terms. In 1999, Professor Jerzy Milewski wrote that Batory could once again become a symbol of Grodno if Belarusians recognize the traditions of the Grand Duchy of Lithuania and the Polish-Lithuanian Commonwealth, in which they were an equal element, as part of their own tradition (Karaŭ, 2004, p. 171).

The famous Belarusian writer Uladzimir Arlov and the authoritative historian Anatol Grytskevich (Gryckevič, 1994; Gryckevič, 1999) did much to awaken the memory of Stefan Batory in the 1990s. Through the efforts of historians, writers and journalists of the Republic of Belarus in the 1990s, the return of this statesman and his epoch to the historical memory of the Belarusian people began (Popov, 1998; 
Selverstova, Šeršenevič, 1992; Šaǔcoǔ, 1996; Ânuškevič, 1998; Karev, Litvinskij, 2013).

Grodno historians have played an important role in this process of return, which continues to this day. International scientific conferences and round tables dedicated to Stefan Batory, organized by Dmitry Karav, an associate professor, then professor of the Yanka Kupala State University of Grodno and by the Humanitarian Centre for Eastern European Studies created by him, became a phenomenon of European historiography. In 1996, the conference entitled Stefan Batory and Eastern Europe of His Time, dedicated to the $410^{\text {th }}$ anniversary of his death, was held in Grodno. It has attracted a significant scientific force of foreign experts. The $470^{\text {th }}$ anniversary of the birth of this ruler and commander in 2003 was marked by the international round table Stefan Batory in the Historical Memory of the People of Eastern Europe (Karaŭ, 2004).

These scientific events, along with a series of conferences Our Genealogy held by D.U. Karav and their published materials, played an important role in ensuring the recognition of the Grodno school of historians in the European scientific world.

These scientific activities gave the Grodno researchers of the $16^{\text {th }}-17^{\text {th }}$ centuries strong motivation to research issues related to Batory. Then N. Kozlovskaya referred to the problem of the formation of the political elite of the Grand Duchy of Lithuania in the time of S. Batory (Karaǔ, 2004, pp. 18-24); G. Vasyuk - to the confessional situation in the Commonwealth at that time (Karaú, 2004, pp. 25-33), A. Semyanchuk - to the historiography of the Commonwealth (Karaǔ, 2004, p. 75-83), and A. Shalanda - to GDL heraldry during the reign of Batory (Karaŭ, 2004, pp. 59-66); S. Yanchalovskayato the image of the King in the art of the $16^{\text {th }}-19^{\text {th }}$ centuries. (Karaǔ, 2004, pp. 90-121); and S. Marozav - to the history of his stay in Grodno (Karaǔ, 2004, pp. 4-17). Articles by the historians of the Yanka Kupala State University of Grodno A. Myaleshka, (Karaǔ, 2004, pp. 122-128), T. Kruchkovski (Karaǔ, 2004, pp. 149-165) M. Kalatsey (Karaǔ, 2004, pp. 172-178), and D. Karav and A. Litvinsky (Karaǔ, 2004, pp. 129$148 ; 23)$ were devoted to the reflection of S. Batory in the historiographical tradition of the people of Eastern and Central Europe.

At the turn of the $20^{\text {th }}-21^{\text {st }}$ centuries, the study of the figure of Batory and the Batory age from the Belarusian point of view and the position of the interests of the Grand Duchy of Lithuania was initiated. Grodno historians highly appreciate the merits of Stefan Batory to the Grand Duchy of Lithuania, Belarus and Grodno. The fact that they recognize the equality of the Principality and the Crown as subjects of a federal state, the obligation given to them to preserve the independence of the Grand Duchy of Lithuania, to return the lands captured by Ivan the Terrible in the Livonian War, etc. is especially emphasized. The Statute of the Grand Duchy of Lithuania of 1588 , adopted two years after Batory, has already fully guaranteed the absolute economic, state, political, and cultural independence of the Principality. In fact, that by the middle of the $17^{\text {th }}$ century, the Grand Duchy of Lithuania was an equal participant in the Polish-Lithuanian Commonwealth and an equal partner of Poland, historians see a considerable merit of Batory. Historians consider Batory's considerable merit in the 
fact that by the middle of the $17^{\text {th }}$ century, the Grand Duchy of Lithuania was an equal participant in the Polish-Lithuanian Commonwealth and an equal partner of Poland.

Scientific memory awakens the everyday memory of Grodno citizens. In relation to Batory, three approaches are conventionally distinguished in the mass historical consciousness of Grodno residents. The first: Batory was our Belarusian leader. He was a strong political figure who was respected in both the West and the East. He made Grodno a royal city. Therefore, a monument should be erected to him, a square should be named after him and his memory should be honoured. The second: Batory is not ours. He is considered with disgust to be a Catholic (although he was Hungarian), who favoured the Jesuits and 'suppressed' the locals. In fact, they reject him in their history. The third: Those who are neutral about the figure of Batory agree that it is necessary to honour the memory of people who have positively influenced the development of the city but they usually do not know what exactly they should be honoured for.

Meanwhile, it is important to note that most citizens have heard of Stefan Batory in one way or another; they know that he is connected with the history of Grodno, at least that he died in Grodno. Although the citizens are divided into several camps in their attitude to this historical figure, they do not remain indifferent.

From time to time there are proposals to put up a monument to him or to name the Soviet Square after him. In 1998, it was planned to install an equestrian monument to Stefan Batory by the sculptor Valery Kolyasinsky in the square near the Fara Church. A series of works by this master, dedicated to Batory, was formed in the whole Batoryana.

In 2016, the public of the city again raised the issue of establishing a monument to the famous Batory in Grodno, and a collection of signatures was organized under a petition to local authorities. It was said in the petition:

Stefan Batory was the ruler of the Polish-Lithuanian Commonwealth, who turned Grodno into the second capital of the state. The Old Castle of Grodno was reconstructed and the main Catholic church, Vytautas Fara, was built. Batory invited representatives of the Jesuit Order to Grodno, who made a great contribution to the development of the education and medicine; and contributed to a significant increase in the city's prestige in the region and abroad. (In Grodno, the citizens began to collect signatures for the installation of the monument to Stefan Batory).

In one day, 600 people signed the petition. More than 70 people left their comments online. Comments are different: from 'Enough to promote Polishness here' to 'This man wanted to move the capital of the Polish-Lithuanian Commonwealth to Grodno, our city was his main residence. Surprisingly, the monument to him may even be in question. It should have been done 20 years ago'. The comments are dominated by a positive attitude towards Stefan Batory, such as 'The King worthy of the memory of Grodno residents', 'the Ruler, a thousand times honoured for Grodno'. It is a pity that the chance to get permission for the installation of the monument is minimal, because for Russians 'Vanya the Terrible is in favour, and Batory beat him' (V Grodno načali 
sobirat' podpisi za ustanovku pamâtnika Stefanu Batoriû (In Grodno the citizens began to collect signatures for the installation of the monument to Stefan Batory).

Among the most significant monuments left behind in Grodno by Stefan Batory are the Old Castle, the 'Batoryevka' and the Vytautas Fara, which, destroyed during the Soviet era, became a symbol of Grodno.

It may seem strange, but the Vytautas Fara is so vivid in memory, it is as if it were not destroyed half a century ago. The residents of the city at various levels have repeatedly called for the restoration of the temple. In place of Fara there is a monument to the lost temple. In 2014, during its opening, the world 3D model of Vytautas Fara was recreated in the sky. Today, as Grodno is developing as a tourist centre, the city public opinion is particularly concerned about the idea that the reconstruction of the temple will acquire a new practical meaning. The church can be restored at the expense of public donations - the contribution of Grodno residents can become a kind of symbol of national unity.

The second most important 'place of remembrance' you may say is the Old Castle. This is one of the oldest architectural monuments in Belarus. The beginning of a number of complex defensive, secular and religious buildings on the Castle Hill, it dates back to the $11^{\text {th }}$ century. This is the only preserved royal castle in Belarus (except for the New Castle). Reconstruction is underway today. This was preceded and continues to be a fierce scientific debate, in what form to restore the Castle? They decided that the Castle should look like it was built in the time of Stefan Batory. Construction is in full swing, although there is still no consensus on some aspects. Among the citizens, who are not indifferent to the appearance of the Castle, it is sometimes said that it would be better not to touch it at all; because they will make another move according to modern standards of housing construction. Some say: 'So as not to forget to put the elevator in, as in Mir Castle, and plastic windows'.

On Savetskaya Square (formerly Batory) there is a palace called 'Batoryevka', which during the construction of the royal palace on the Castle Hill served as the residence of the ruler of the Commonwealth. By the beginning of the $18^{\text {th }}$ century it was the most representative secular building in the city, the most famous building in the city at the level of historical memory as it was here that the first autopsy of the deceased took place in Eastern Europe - doctors were looking for the cause of death of King Stefan. This place is also known for the legend of the underground city, which stretches from 'Batoryevka' to the former town Hall, the Vytautas Fara, the royal castle and, as they say, even to the other bank of the Neman and somewhere outside the city.

The 'Batoryevka' consisted of several parts - the older one has not been preserved. At this place, there is now a five-story residential building, on the ground floor of which there is the shop 'Batorya'. At first glance, the feminine gender of the name is surprising. But according to Grodno local historian Viktar Sayapin, Eliza Ozheshko often used the name 'Batorya house' along with the toponym 'Batoryevka'. Probably, this folk toponym also entered into the name, having lost the word 'house' (Caâpin).

Recently, on December 12, Grodno mass media, including online media, reminded Grodno citizens that this is the day of Stefan Batory's memory. On the anniversary 
of the destruction of the Vytautas Fara, on the site of which the monument to the lost temple was recently erected, blocks of material about its history appear, and new circumstances of this tragedy are gradually being revealed. The tour guides have developed a tour Stefan Batory's Grodno Ways, which is in great demand among tourists. The Stefan Batory Festival, which was launched in Grodno on the initiative of the reconstructors from Poland, is supposed to give a strong impetus to the tourism business of Belarus. The first such festival was timed to the $430^{\text {th }}$ anniversary of the King's death (Grodzieńskie obchody).

Thus, Grodno is a 'place of memory', an 'address of memory' about Stefan Batory. The attitude toward this historical figure in science and society changed three times during the $20^{\text {th }}$ century: from the strong presence in the tradition of Grodno in 1919-1939, through the transformation into a 'white spot' of the Soviet-era history, to the return to historical memory that began in 1990. Modern Grodno historians, first of all on the scientific initiative of Professor D. Karav, have made a significant contribution to the study of the activities of Stefan Batory in the space of his time and the historiographical tradition of the people of Eastern and Central Europe. This, together with the efforts of Grodno local historians, teachers, museum workers, and guides, contributed to the return of the name and deeds of Batory to the historical memory of citizens.

The article was prepared as part of the research work The Grand Duchy of Lithuania in the historical memory of Belarusian society (19th - early $21^{\text {st }}$ century), which is carried out with the financial support of the Belarusian Republican Foundation for Basic Research.

Translated into English by Marharyta Svirydava

\section{List of Sources}

DAGO - State Archive of the Grodno Region, f. 46, inv. 1, d. 281.

\section{References}

Ânuškevič A. (1998). Prysâga Stèfana Batoryâ [pra pahod knâzâ S. Batoryâ na Polack u 1579 g.]. Belaruskâ̂ minuǔščyna, 1, pp. 7-10. [Янушкевіч А. (1998). Прысяга Стэфана Баторыя [пра паход князя С. Баторыя на Полацк у 1579 г.]. Беларуская мінууцичына, 1, c. 7-10].

Bibliografiâ Iosifa Iodkovskogo. [Библиография Иосифа Иодковского]. Taken from: http:// skarbonka.ru/num-ka/numizmaty/jodk/11-bibliografiya-iosifa-iodkovskogo (accessed: 08.03.2020). 
Caâpin, V. «Batorievka i ee obitateli», dostoprimečatel'nosti Grodno. [Саяпин В. «Баториевка и ее обитатели», достопримечательности Гродно]. Taken from: http://zetgrodno. com/v.sayapin-batorievka-i-eyo-obitatel (accessed: 08.03.2020).

Filûškin, Aleksandr; Kuz'min, Andrej. (2017). Kogda Polock byl rossijskim. Polockaâ kampaniâ Ivana Groznogo 1563-1579. Moskva: Russkie Vitâzi. [Филюшкин, Александр; Кузьмин, Андрей. (2017). Когда Полоцик был российским. Полоцкая кампания Ивана Грозного 1563-1579. Москва: Русские Витязи].

Grodzieńskie obchody 430. rocznicy śmierci Króla Stefana Batorego. Taken from: http:// znadniemna.pl/19919/grodzienskie-obchody-430-rocznicy-smierci-krola-stefanabatorego/ (accessed: 08.03.2020).

Gryckevič, Anatol'. (1994). Stèfan Batoryj ì Garodnâ. Belaruskì gìstaryčny časopìs, 4, pp. 2227. [Грыцкевіч, Анатоль. (1994). Стэфан Баторый і Гародня. Беларускі гістарычны yaconic, 4, c. 22-27].

Gryckevič, Anatol'. (1999). Stafan Batoryj ì Goradzen. In: G. Paškoǔ (ed.) Pamâc': Gìstorykadakumental'naâ hronika gorada Grodna (pp. 76-79). Mìnsk: Belaruskaâ Èncyklapedyâ ìmâ P. Broǔkì. [Грыцкевіч, Анатоль. (1999). Стафан Баторый і Горадзен. У: Г. Пашкоў (ed.) Памяць: Гісторыка-дакументальная хроніка горада Гродна (с. 76-79). Мінск: Беларуская Энцыклапедыя імя П. Броўкі].

Jankowski, Tadeusz. (1930). Śmierć Stefana Batorego w Grodnie. Grodno: Wydawnictwo Magistratu Miasta Grodna.

Karaǔ, Dzmitryj (editor-in-chief/compiler). (2004). Stèfan Batoryj u gistaryčnaj pamâcì narodaǔ Ushodnâj Eǔropy. Matèryâly mižnarodnaga kruglaga stala (Grodna, 26 verasnâ 2003 g.). Grodna: GCCUE. [Караў, Дзмітрый (адказны рэдактар /ўкладальнік). (2004). Стээан Баторый у гістарычнай памячі народаў Усходняй Еўропы. Матэрыяль міжнароднага круглага стала (Гродна, 26 верасня 2003 г.). Гродна: ГЦЦУЕ].

Karev, Dmitrij; Litvinskij, Aleksandr. (2013). Stefan Batorij i ego èpoha v istoriografičeskoj tradicii zapadnorusizma (konec XIX - načalo XX v.). In: Kraâznaǔčyâ zapiskì: zbornìk artykulaǔ. Issue 9. (pp. 63-85). Grodna: Upraǔlenne kul'tury Grodzenskaga ablvykankama, Ustanova kul'tury „Grodzenskì dzâržaǔny gìstoryka-arhealagičny muzej”. [Карев, Дмитрий; Литвинский, Александр. (2013). Стефан Баторий и его эпоха в историографической традиции западнорусизма (конец XIX - начало XX в.). У: Краязнаўчыл запіскі: зборнік артыкулаў. Вып. 9. (с. 63-85). Гродна: Упраўленне культуры Гродзенскага аблвыканкама, Установа культуры „Гродзенскі дзяржаўны гісторыка-археалагічны музей"'].

Kazak, Taccâna. (2013). Ušanavanne pamâcì Stèfana Batoryâ ǔ Grodne ǔ mǐžvaenny čas. Kraâznaǔčyâ zapiskì: zbornìk artykulaǔ, 9, pp. 124-131. [Казак, Таццяна. (2013). Ушанаванне памяці Стэфана Баторыя ў Гродне ў міжваенны час. Краязнаўчыя запіскі: зборнік артыкулаў, 9, с. 124-131].

Laškevič, Sârgej. (2010). Ushodni nakirunak dyplamatyčnaj dzejnascì Vâlikaga knâstva Litoǔskaga ǔ apošnâj trèci XVI st. Mìnsk: Prava ì èkanomìka. [Лашкевіч, Сяргей. (2010). Усходні накірунак дыпламатьчнай дзейнасиі Вялікага княства Літоўскага у апошняй трэці XVI cm. Мінск: Права і эканоміка]. 
Milewski, Jerzy. (1999). Stefan Batory w tradycji Grodna 1919-1939. In: Dzmìryj Karaŭ, Aleg Latyšonak (eds.). Belarusy ì palâkì: dyâlog narodaǔ i kul'tur. X-XX st. Matèryâly mižnarodnaga kruglaga stala (Grodna, 28-30 verasnâ 1999 g.) (pp. 462-467). Grodna: Naš Radavod. [У: Дзмірый Караў, Алег Латышонак (eds.). Беларусы і палякі: дыяллог народаў $і$ культур. Х-ХХ ст. Матэрыяль міжнароднага круглага стала (Гродна, 28 30 верасня 1999 г.) (с. 462-467). Гродна: Наш Радавод].

Novodvorskij, Vitol'd. (2015). Ivan Groznyj i Stefan Batorij: shvatka za Livoniû. Moskva: Lomonosov". [Новодворский, Витольд. (2015). Иван Грозный и Стефан Баторий: схватка за Ливонию. Москва: Ломоносовъ].

Orlovskij E. (2011). Očerk istorii goroda Grodny. In: Grodnenŝina. Part. 1. Istoriâ, kraevedenie, ètnografiâ: po materialam Pamâtnyh knižek Grodnenskoj gubernii: v 2 t. [auth.- comp. A. Ryžij]. [Facsimile edition] (Vol. 2, pp. 69-143). Grodno: ÛrSaPrint. [Орловский Е. (2011). Очерк истории города Гродны. У: Гродненщина. Ч. 1. История, краеведение, этнография: по материалам Памятных книжек Гродненской губернии: в 2 m. / [авт.сост. А. Рыжий]. [Факсимильное издание] (Т. 2, с. 69-143). Гродно: ЮрСаПринт].

Penskoj, Vitalij. (2019). Polockaâ vojna. Očerki istorii russko-litovskogo protivostoâniâ vremen Ivana Groznogo. 1562-1570. Moskva: Centrpoligraf. [Пенской, Виталий. (2019). Полоикая война. Очерки истории русско-литовского противостояния времен Ивана Грозного. 1562-1570. Москва: Центрполиграф].

Popov, F. (1998). Vozvraщеnиe Stefana Batoruâ v Grodno. Narodnâ̂ volâ, March 18, p. 2. [Попов Ф. (1998). Возвращение Стефана Батория в Гродно. Народная воля, 18 сакавіка, с. 2].

Šaǔcoǔ, Ûry. (1996). Bataryânskaâ partyâ. Spadčyna, 2, pp. 89-118. [Шаy̆цоy̆, Юры. (1996). Батарыянская партыя. Спадчына, 2, с. 89-118].

Scheuring Herman. (1964). Czy królobojstwo? Krytyczne studium o śmierci króla Stefana Batorego. Londyn.

Sel'verstova, S.; Šeršenevič, A. (1992). Pravo na pamât'. Grodnenskaâ pravda, April 4, pp. 2-3. [Сельверстова, С.; Шершеневіч, А. (1992). Право на память. Гродненская правда, 4 апреля, с. 2-3].

Sprawozdanie Wojewodzkiego Komitetu Uczczenia Krola Stefana Batorego z prac na Starym Zamku w Grodnie, 1933-1937. (1938). Grodno: Woj. Kom. Uczczenia Krola Stefana Batorego w Grodnie.

The Death of Stephan Bathory in Grodno 12th December, 1586. (2018). Minsk: Belarus.

V Grodno načali sobirat' podpisi za ustanovku pamâtnika Stefanu Batoriû. [В Гродно начали собирать подписи за установку памятника Стефану Баторию]. Taken from: https:// grodno.in/news/14221/ (accessed: 08.03.2020).

W rocznicę 15331918 1933. Jednodniówka Akademickiego Oddziału Związku Strzeleckiego w Grodnie. (1933). Grodno: Oddział Związku Strzeleckiego.

Ziembicki, Witold. (1937). Ostatnie łowy Batorego. W 350 rocznicę zgonu wielkiego króla (grudzień 1586 - grudzień 1936). Lwów: Drukarnia Księgarni Polskiej Bernarda Połonieckiego. 